\title{
Uranium-Series Constraints on Radionuclide Transport and Groundwater Flow at the Nopal I Uranium Deposit, Sierra Peña Blanca, Mexico
}

Steven J. Goldstein ${ }^{1 *}$, Amr I. Abdel-Fattah ${ }^{2}$, Michael T. Murrell ${ }^{1}$, Patrick F. Dobson ${ }^{3}$, Deborah E. Norman ${ }^{1}$, Ronald S. Amato ${ }^{1}$ and Andrew J. Nunn ${ }^{1}$

${ }^{1}$ Nuclear and Radiochemistry Group, Los Alamos National Laboratory, P.O. Box 1663, MS J514, Los Alamos, New Mexico 87545, USA.

${ }^{2}$ Hydrology, Geochemistry, and Geology Group, Los Alamos National Laboratory, P.O. Box 1663, MS J514, Los Alamos, New Mexico 87545, USA.

${ }^{3}$ Earth Sciences Division, Lawrence Berkeley National Laboratory, Berkeley, California, 94720 USA

*Corresponding Author: sgoldstein@lanl.gov

\begin{abstract}
Uranium-series data for groundwater samples from the Nopal I uranium ore deposit were obtained to place constraints on radionuclide transport and hydrologic processes for a nuclear waste repository located in fractured, unsaturated volcanic tuff. Decreasing uranium concentrations for wells drilled in 2003 are consistent with a simple physical mixing model that indicates that groundwater velocities are low $(\sim 10 \mathrm{~m} / \mathrm{y})$. Uranium isotopic constraints, well productivities, and radon systematics also suggest limited groundwater mixing and slow flow in the saturated zone. Uranium isotopic systematics for seepage water collected in the mine adit show a spatial dependence which is consistent with longer water-rock interaction times and
\end{abstract}


higher uranium dissolution inputs at the front adit where the deposit is located. Uranium-series disequilibria measurements for mostly unsaturated zone samples indicate that ${ }^{230} \mathrm{Th} /{ }^{238} \mathrm{U}$ activity ratios range from $0.005-0.48$ and ${ }^{226} \mathrm{Ra} /{ }^{238} \mathrm{U}$ activity ratios range from $0.006-113 .{ }^{239} \mathrm{Pu} /{ }^{238} \mathrm{U}$ mass ratios for the saturated zone are $<2 \times 10^{-14}$, and Pu mobility in the saturated zone is $>1000$ times lower than the U mobility. Saturated zone mobility decreases in the order ${ }^{238} \mathrm{U}^{226} \mathrm{Ra}>$ ${ }^{230} \mathrm{Th} \sim{ }^{239} \mathrm{Pu}$. Radium and thorium appear to have higher mobility in the unsaturated zone based on U-series data from fractures and seepage water near the deposit.

Revised version to Environmental Science and Technology, Novermber 2009. 


\section{Introduction}

Geological barriers are an important possible mechanism for isolation of radioactive contaminants from the biosphere. One measure of the effectiveness of such barriers is determination of retardation factors, i.e. the transport rate of contaminants relative to groundwater. Uranium-series techniques are an important method for determining in-situ retardation factors in groundwater (e.g. 1-3). In a geochemical system that is closed for greater than five daughter half-lives, the activity of each U-series daughter will be equivalent to its parent nuclide. This is true for rocks that have been closed systems for approximately one million years. However, as U-series nuclides are dissolved in groundwater during water-rock interaction, chemical fractionations may occur between different elements which result in disequilibria among U-series nuclides. For long-lived U-series daughters where decay in groundwater is negligible, the magnitude of U-series disequilibria is proportional to the relative mobility of each U-series nuclide in groundwater. As an approximation, the extent of U-series disequilibria is also inversely related to relative retardation factors. Hence, measurement of long-lived daughters such as ${ }^{234} \mathrm{U},{ }^{230} \mathrm{Th},{ }^{226} \mathrm{Ra}$, and ${ }^{239} \mathrm{Pu}$ can be used to directly determine their relative mobility or retardation in groundwater.

We have applied these techniques to study groundwater flow and radionuclide transport near the Nopal I uranium deposit located in the Peña Blanca region, Chihuahua, Mexico (Fig. 1). This area, approximately $50 \mathrm{~km}$ north of Chihuahua City, was a major target of uranium exploration and mining by the Mexican government in the 1970’s. More recently, this deposit has been extensively studied as an analog for evaluating the fate of spent fuel, associated actinides, and fission products at a geologic repository in fractured, unsaturated volcanic tuff. Briefly, the 
deposit represents an environment similar to the proposed U.S. Yucca Mountain high-level radioactive waste repository in the following ways, 1) climatologically, both are located in semiarid to arid regions, 2) structurally, both are parts of a basin-and-range horst structure composed of Tertiary rhyolitic tuffs overlying carbonate rocks, 3) hydrologically, both are located in a chemically oxidizing environment within an unsaturated zone, $200 \mathrm{~m}$ or more above the water table, and have broadly similar water chemistries, and 4) chemically, because the alteration of primary uraninite (4) to secondary uranium minerals at Nopal I may be similar to the eventual fate of uranium fuel rods in a geologic repository according to results of spent-fuel alteration experiments (5). In this study, we measured long-lived U-series nuclide abundances in groundwater from this site by sensitive mass spectrometric methods. U-series measurements, including our measurements of ${ }^{238} \mathrm{U}^{239} \mathrm{Pu}$ disequilibrium, are used to constrain recent radionuclide transport and groundwater hydrologic processes at this location. This provides a unique opportunity to follow transport of U-series nuclides in three dimensions from a welldefined source term, namely the ore body. Our study may add to the conceptual understanding of similar processes at the proposed Yucca Mountain repository or other waste disposal sites in semi-arid, unsaturated zone settings.

\section{Samples and Methods}

Saturated zone (SZ) waters were collected from 6 wells near the Nopal I uranium deposit, and seepage waters from the unsaturated zone (UZ) were obtained from an adit at the Nopal I mine (Figs. 1-2). SZ intervals of the PB1, PB2, and PB3 wells, located immediately adjacent to the Nopal I ore deposit, occur mostly within Pozos conglomerate, with the lowest section of each well in Cretaceous limestone (6). SZ intervals for two wells located SE of the Nopal I deposit, 
PB4 and Pozos Ranch, are totally within Cretaceous limestone. The subsurface geology at Peña Blanca Ranch is not constrained near the water table.

UZ water sample locations from the mine adit are shown in Fig. 2. The mine adit is located at the +00 level of the deposit near PB1. UZ rocks near the mine adit consist of rhyolitic welded ash-flow tuffs (Nopal and Coloradas Formations) that host the ore deposit (6). Groundwater samples from the adit and regional wells were collected during 2000-2006, whereas samples from the PB1, PB2, and PB3 wells have been collected from 2003-2006.

SZ water samples were mostly collected by bailer, but in two instances (December 2003 and August 2006) by pump. UZ water samples were collected from the mine adit via two collection systems (Fig. 2), initially a drip collection system consisting of plastic sheeting and later a rigid plastic grid that was designed to funnel water into plastic bottles. Water samples for U-series analyses were filtered ( $0.20 \mu \mathrm{m}$ or $0.45 \mu \mathrm{m}$ filters) after collection and acidified to a $\mathrm{pH}$ of $1-2$ with high purity nitric acid for long-term storage. Samples from the PB1 and PB4 wells collected specifically for colloid analysis were stored in coolers immediately after collection and refrigerated until analysis. These samples were ultrafiltered in the laboratory using separate sterile ultrafiltration stirred cells (Millipore, USA), equipped with both $300 \mathrm{kDa}$ (kilodalton) membrane filters and 20-nm in-line syringe filters. U concentrations of unfiltered and filtered splits were measured to determine how much of the $\mathrm{U}$ is associated with colloids.

Uranium, thorium, radium, and plutonium samples were analyzed as separate aliquots and each spiked with ${ }^{233} \mathrm{U},{ }^{229} \mathrm{Th},{ }^{228} \mathrm{Ra}$, or ${ }^{244} \mathrm{Pu}$ tracer. After tracer equilibration, uranium was purified using anion exchange columns and loaded onto single or triple Re filaments (7). Uranium isotopes $\left({ }^{238} \mathrm{U},{ }^{235} \mathrm{U},{ }^{234} \mathrm{U}\right)$ were measured multi-statically using a GV Sector 54 mass 
spectrometer equipped with multiple Faraday cups and a Daly ion counting detector. Calibration between Daly and Faraday detectors was determined by switching the ${ }^{235} \mathrm{U}$ beam between these collectors, and instrumental mass fractionation was corrected by normalization to the natural ${ }^{238} \mathrm{U} /{ }^{235} \mathrm{U}$ ratio of 137.88 .

Radium was purified using cation exchange columns for the major element separation, EDTAcation columns for Ra-Ba separation, and a final cation exchange column to rid the samples of EDTA. Radium was loaded onto Pt filaments using a silica gel enhancer and analyzed dynamically on a NBS 12-90 sector mass spectrometer equipped with a SEM ion counting detection system (8).

Thorium was purified using an $\mathrm{HCl}$ anion column for Th-U separation and a nitric acid anion column for major element separation (7). Thorium was analyzed using the Isoprobe-P MCICPMS with multistatic collection of ${ }^{232} \mathrm{Th}$ and ${ }^{229} \mathrm{Th}$ on Faraday cups and ${ }^{229} \mathrm{Th}$ and ${ }^{230} \mathrm{Th}$ on a Daly detector. Samples were bracketed with gravimetric thorium standard solutions of known ${ }^{232} \mathrm{Th} /{ }^{229} \mathrm{Th}$ ratio to correct for instrumental mass fractionation and calibrate the gains between Daly and Faraday detectors.

Plutonium was purified using coprecipitations followed by anion exchange columns. The purified plutonium was then loaded onto a single resin bead that was placed in a single Re canoe carburized filament. Plutonium isotopes were measured dynamically on a GV Sector 54 mass spectrometer equipped with a Daly ion counting detector.

Measurement accuracy for both $U$ concentration and ${ }^{234} U /{ }^{238} U$ ratio was verified by measurement of NBS U-960 and NIST 4321C natural uranium standard reference materials. For 
uranium and radium, filtration and process blanks are negligible in comparison to sample size. A ${ }^{232}$ Th blank correction of $\sim 43$ pg was applied to the data, corresponding to $<$ one-third of the

${ }^{232}$ Th signals measured. For ${ }^{239} \mathrm{Pu}$, an isobaric interference corresponding to the equivalent of 35 atoms ${ }^{239} \mathrm{Pu} / \mathrm{g}$ sample was subtracted from the data and is similar in size to the total ${ }^{239} \mathrm{Pu}$ signal for each sample. Hence, no ${ }^{239} \mathrm{Pu}$ was detected in the samples, with an upper limit of $\sim 50$ atoms ${ }^{239} \mathrm{Pu} / \mathrm{g}$ sample.

\section{Results and Discussion}

Uranium concentrations and ${ }^{234} \mathrm{U} /{ }^{238} \mathrm{U}$ ratios for SZ and UZ samples collected in 2003-2006 are given in Tables S1-S2. Long-lived uranium-series results $\left({ }^{238} \mathrm{U},{ }^{234} \mathrm{U},{ }^{230} \mathrm{Th},{ }^{226} \mathrm{Ra}\right)$ for samples collected in 2000-2001 are shown in Table 1. Uranium concentrations and ${ }^{234} \mathrm{U}^{238} \mathrm{U}$ ratios for unfiltered, filtered, and ultrafiltered samples are given in Table S3.

\section{Uranium constraints on groundwater flow in the saturated zone}

In 2003, three groundwater wells were drilled directly adjacent to (PB1) and $\sim 50 \mathrm{~m}$ on either side of the Nopal I uranium deposit (PB2 and PB3). After drilling, U concentrations were elevated in all three wells (0.1-18 mg U/kg) due to drilling activities. $\mathrm{pH}$ values were as high as 11.3 from detergents in the drilling fluids, and interaction of these high $\mathrm{pH}$ fluids with surrounding rock led to the high $\mathrm{U}$ concentrations. $\mathrm{pH}$ decreased in a matter of a few months (by July 2003) to more typical groundwater values $(\mathrm{pH}=7-9)$. Well productivity and SZ permeability obtained from pump tests (9) decreases in the order PB3>PB1>PB2, and this correlates with initial U concentrations. This suggests that wells with higher permeability had greater waterrock interaction. PB1 and PB2 wells were characterized by very low productivities and permeabilities (9). As shown in Fig. 3, U concentrations for the new wells have exponentially 
decreased over time, although well pumping and conditioning in December 2003 and August 2006 disturbed this general trend.

Uranium isotopic and concentration data for the SZ are shown in Fig. 4, in which conservative mixing between components results in linear trends. ${ }^{234} \mathrm{U} /{ }^{238} \mathrm{U}$ activity ratios are similar for PB1-PB2 (1.005-1.090) but higher for PB3 (1.36-1.97) over the 2003-2006 time period. These data, along with results of pumping (9) which found drawdown of PB1 during PB2 pumping and vice versa, suggest interconnectivity between the PB1-PB2 wells. However, PB1-PB2 water is distinct from PB3 in both [U] and ${ }^{234} \mathrm{U} /{ }^{238} \mathrm{U}$. Regional groundwater wells located several km from the deposit also have distinct $\mathrm{U}$ isotopic characteristics, indicative of multiple components of uranium. Results for 11 water samples collected from the Chuviscar River, located near Aldama, $~ 50 \mathrm{~km}$ south of the Nopal I mine, are also given in Fig. 4 with ${ }^{234} \mathrm{U} /{ }^{238} \mathrm{U}$ activity ratios $=4.3+/-0.2(1 \mathrm{sd} ;(10))$. The river drains alluvial fans and volcanic rocks of Sierra la Gloria which are similar to those in the Peña Blanca uranium district. Multiple components shown in Fig. 4 consist of 1) a high $U$ component with ${ }^{234} U /{ }^{238} U$ activity ratios near unity, as would result from bulk dissolution of a rock in secular equilibrium, 2) a high $U$, high ${ }^{234} U{ }^{238} U$ component, which reflects a greater recoil-related ${ }^{234} U /{ }^{238} \mathrm{U}$ signature, and 3) a component with ${ }^{234} \mathrm{U} /{ }^{238} \mathrm{U}$ activity ratio near unity and low $\mathrm{U}$ concentration. Varying uranium concentrations of the components may be generated by any number of processes including dissolution/precipitation/sorption and evaporation/dilution.

Decreasing uranium concentrations in the new wells can be modeled in a variety of ways, including physical and chemical models or combinations thereof. Here we present a simple 
physical model that places order of magnitude constraints on groundwater flow velocity. We use a one-dimensional tank model, where the tank consists of the SZ well volume that is continuously flushed with groundwater (11). We assume that uranium is introduced as a slug to each of the wells and transported as a conservative tracer by groundwater flow. Hence, $\mathrm{U}$ concentration is a simple function of groundwater flow velocity or specific discharge. Since background $\mathrm{U}$ in groundwater is negligibly small compared to the $\mathrm{U}$ defined by the initial slug, we obtain the following relations derived for this study:

$$
\begin{aligned}
& d C / d t=-2 q h r C / V \\
& q=\frac{V}{2 h r\left(t_{2}-t_{1}\right)} \ln \left(C_{1} / C_{2}\right)
\end{aligned}
$$

where $q$ is the groundwater specific discharge, $V$ is the saturated zone well volume (163-208 L), $h$ is the casing perforation height $(9.15-12.20 \mathrm{~m}), C_{1}$ is the $\mathrm{U}$ concentration at time $t_{1}$ and $C_{2}$ that at $t_{2}$, and $r$ is the well casing internal radius $(4.825 \mathrm{~cm})$. The model is only approximate, and additional factors are often included to account for flow distortion or skin effects from drilling, which can modify flow through the borehole relative to the surrounding formation (e.g. 11). Consideration of the most likely chemical effect (U precipitation) would decrease the flow required to decrease $\mathrm{U}$ concentrations with time, hence the physical model above may provide an upper limit on groundwater flow rates.

The most reliable velocity data are likely obtained from the initial decrease in $\mathrm{U}$ concentration in 2003, when the model is relatively unaffected by the background U in groundwater. Using 2003 data for all three wells, the model yields specific discharge of $0.7-2.3 \mathrm{~m} / \mathrm{y}$. Using porosity measurements for the Pozos conglomerate of $\mathrm{n} \sim 15 \%$ (6), this corresponds to groundwater flow 
velocities ranging from $v=5-15 \mathrm{~m} / \mathrm{y}$, where $\mathrm{v}=\mathrm{q} / \mathrm{n}$, and $\mathrm{n}=$ porosity. The slow flow velocities obtained are consistent with interconnectivity between PB1-PB2 observed during field tests (9), as much larger flow rates would be expected during active pumping. ${ }^{222} \mathrm{Rn}$ measurements taken before and after pumping PB1 in August 2006 also indicate a relatively low specific discharge of $\sim 2 \mathrm{~m} / \mathrm{y}$ (12). Consequently, the uranium concentration and isotopic results, low well productivities, and ${ }^{222} \mathrm{Rn}$ constraints suggest slow saturated zone groundwater flow with little or no regional scale mixing at this location.

\section{Uranium constraints on dissolution inputs and residence times in the unsaturated zone}

Uranium isotopic systematics for all adit waters collected from 1995-2006, including results obtained independently by (13) are shown in Fig. 5 and appear to show a spatial dependence. In general, the overall range of ${ }^{234} U /{ }^{238} U$ activity ratios for the UZ (1-6) and SZ (1-5) are similar (Figs. 4- 5). The front adit generally has ${ }^{234} U{ }^{238} U$ activity ratios near unity and higher $U$ concentrations, as would result from dissolution of a rock in secular equilibrium. The rear adit is characterized by high ${ }^{234} \mathrm{U} /{ }^{238} \mathrm{U}$ activity ratios from 2-5 and variable $\mathrm{U}$ concentration, indicating a high recoil-related component and $U$ concentration affected by varying $U$ dissolution fluxes and/or rock-water interaction times. Finally, the middle adit appears to be a mixture of these two endmembers. There may also be a seasonal dependence, with samples collected in the wet monsoon season (July-December) tending to have higher ${ }^{234} \mathrm{U} /{ }^{238} \mathrm{U}$ and greater recoil signature than those collected in the January-June dry season (14). Here we discuss the stronger spatial dependence only. 
These results can be evaluated using a model simulating a non-steady state situation for uranium isotope transport in groundwater, which provides constraints on in-situ radioisotope migration in dissolved and colloidal phases in terms of retardation factor and water-rock interaction time $(2,14)$. For uranium, the model is based on the fact that water passing through the UZ has its $U$ concentration and ${ }^{234} \mathrm{U} /{ }^{238} \mathrm{U}$ ratio modified by $\mathrm{U}$ dissolution from rocks and $\alpha$-recoil input of ${ }^{234} \mathrm{U}$ from rock surfaces. The model predicts that intermittent $\mathrm{UZ}$ flushing gives rise to waters having a linear relationship between $1 /[U]$ and ${ }^{234} U /{ }^{238} U$ (Fig. 5).

The isotope mixing relations seen in Fig. 5 appear scattered, and a linear model can only approximate the results. Similar range and scatter for the U isotopic systematics of UZ water near Yucca Mtn., Nevada was observed by (15). Scatter in both of these studies may be due to imperfect or insufficient sampling of the full range of natural conditions. However, the intercept and slope of the linear approximation reveals consistent results in terms of uranium dissolution inputs and/or water-rock interaction times. Samples from the front and middle adit correspond to low intercept (near secular equilibrium), reflecting increased $U$ dissolution inputs toward the front adit, where the ore deposit is located. Their generally high $\mathrm{U}$ concentration and slope reflect longer rock-water interaction times. High intercept, low slope, and generally lower $\mathrm{U}$ concentration for samples from the back adit suggest that these samples have experienced decreased U dissolution inputs and variable but generally shorter water-rock interaction times. More detailed modeling of these results is presented in (14).

Consistent with these results, shorter seepage times have been observed for the back adit relative to the front, based on rainfall measurements along with seepage results from transducermonitored adit collector columns (P. Dobson, personal communication). Measured matrix 
permeabilities of the Nopal tuff are low ( $<0.1$ millidarcy), thus flow through the altered tuff is predominantly controlled by fracture flow (6). Although there are fractures throughout the adit, the back adit is characterized by greater and more rapid fracture flow than the front adit where the deposit is located. Evaporation during rapid fracture flow in the back adit in the summer monsoon season is expected to be quite limited. However, considerable evaporation can take place during the longer seepage times at the front, and seepage from the front adit generally has higher salinity and lower volume (P. Dobson, personal communication). Similar hydrogen and oxygen isotopic compositions of seepage water from the back adit and summer rainfall, and heavier hydrogen and oxygen compositions for seepage water from the front adit (P. Dobson, personal communication) also support these conclusions.

Our preliminary results suggest that uranium dissolution inputs for the back adit for fractures with water-rock interaction times of $\sim 0.5$ days are $\sim 1 \mathrm{ppb}$ dissolved U/day. It may also be possible to determine dissolution fluxes for a wide range of elements in the UZ in the back adit, where complicating effects of evaporation and mineral precipitation on seepage water elemental abundance are relatively minor. Although we are aware of no other field measurements of this type, the $\mathrm{U}$ dissolution rate above can be compared to laboratory experiments which indicate rapid initial dissolution ( 200-4000 ppb dissolved U/day) of soluble uranyl phases present in the suspended sediment of the Upper Puerco River, New Mexico (16). Our estimate is 2-3 orders of magnitude lower, presumably due to differences in water/rock ratio and uranium characteristics of solid phases. 


\section{Uranium-series constraints on radionuclide mobility}

Our ${ }^{238} \mathrm{U}_{-}{ }^{234} \mathrm{U}_{-}{ }^{230} \mathrm{Th}_{-}{ }^{226} \mathrm{Ra}$ disequilibria measurements for groundwater samples located primarily in the UZ (Table 1) indicate that ${ }^{230} \mathrm{Th} /{ }^{238} \mathrm{U}$ activity ratios range from $0.005-0.48$, and ${ }^{226} \mathrm{Ra} /{ }^{238} \mathrm{U}$ activity ratios range from $0.006-113$. Following equations $(7-9$ or also 4,10$)$ in $(1)$, for groundwater in contact with a solid matrix in secular equilibrium, activity ratios of long-lived Useries nuclides are inversely related to relative retardation factors. The rocks and uranium ores at Peña Blanca have ages $>1 \mathrm{Ma},(6,17)$ and should be near secular U-series equilibrium. In addition, younger secondary minerals deposited in fractures are also near secular equilibrium, with activity ratios ranging from $0.9-1.5$ for ${ }^{234} \mathrm{U} /{ }^{238} \mathrm{U}, 1.0-1.5$ for ${ }^{230} \mathrm{Th} /{ }^{238} \mathrm{U}$, and $0.7-1.2$ for ${ }^{226} \mathrm{Ra} /{ }^{230} \mathrm{Th}(18)$. Consequently, $\left.\mathrm{R}_{\mathrm{f}}\left({ }^{230} \mathrm{Th}\right) / \mathrm{R}_{\mathrm{f}}{ }^{238} \mathrm{U}\right)$ ranges from $\sim 2-200$, and $\mathrm{R}_{\mathrm{f}}\left({ }^{226} \mathrm{Ra}\right) / \mathrm{R}_{\mathrm{f}}\left({ }^{238} \mathrm{U}\right)$ ranges from $\sim 0.009-170$, where $R_{\mathrm{f}}$ is the retardation factor. Because ${ }^{226} \mathrm{Ra} /{ }^{238} \mathrm{U}$ ratios are highest in the UZ and lowest in the SZ, radium appears to have enhanced mobility in UZ waters near the deposit. This observation is similar to results obtained from U-series studies of surface fractures near the deposit, which indicate relatively recent mobility for ${ }^{226} \mathrm{Ra}$ (18). It is also similar to results obtained for vegetation near the deposit (19), which also show high levels of ${ }^{226} \mathrm{Ra}$ relative to ${ }^{230} \mathrm{Th}$ and ${ }^{238} \mathrm{U}$. In the absence of significant Ra/U fractionation upon plant uptake, this would also indicate greater mobility of Ra in the UZ.

We also have studied the ${ }^{238} \mathrm{U}_{-}{ }^{239} \mathrm{Pu}$ disequilibrium systematics for four SZ groundwater samples (PB1, PB2, PB3, and PB4) collected in December 2003. We did not measure any ${ }^{239} \mathrm{Pu}$ in any of the filtered samples, with the corresponding upper limit ${ }^{239} \mathrm{Pu}<50$ atoms/g (see above). Uranium systematic for samples collected at this time are quite reproducible (Table S1), with sample PB3 having the highest $\mathrm{U}$ concentration of $966 \mathrm{ppb}$. Assuming that the Pu in sample 
PB3 would be naturally derived from neutron reactions with ${ }^{238} \mathrm{U}$, comparison of the measured upper limit $\mathrm{Pu} / \mathrm{U}$ ratio $\left(2 \times 10^{-14}\right.$; based on ${ }^{239} \mathrm{Pu}<50$ atoms/g and $\left.\mathrm{U}=966 \mathrm{ppb}\right)$ with the secular equilibrium ratio (based on the average $\mathrm{Pu} / \mathrm{U}$ in old uranium ores of $\sim 2 \times 10^{-11}(20)$ ) provides constraints on the relative mobility of $\mathrm{Pu}$ and $\mathrm{U}$ in the SZ. These results indicate that $\mathrm{Pu}$ mobility in the SZ at Peña Blanca is at least 3 orders of magnitude lower than the $\mathrm{U}$ mobility. Hence, $\left.\mathrm{R}_{\mathrm{f}}{ }^{239} \mathrm{Pu}\right) / \mathrm{R}_{\mathrm{f}}\left({ }^{238} \mathrm{U}\right)$ is calculated to be $>1000$.

By combining long-lived nuclide data from this study with short-lived nuclide data (12), we estimate that $\mathrm{R}_{\mathrm{f}}{ }^{238} \mathrm{U}$ ) varies from $\sim 30$ to 7200 , with an average value of 1300 (Table S4; Fig. 6). Estimates of $\mathrm{R}_{\mathrm{f}}{ }^{238} \mathrm{U}$ ) are obtained from equations 5 and 9 in (2), which in general at Peña Blanca reduce to $\mathrm{R}_{\mathrm{f}}\left({ }^{238} \mathrm{U}\right) \sim \mathrm{A}\left({ }^{222} \mathrm{Rn}\right) / \mathrm{A}\left({ }^{238} \mathrm{U}\right)$, where A denotes activity. Estimated retardation factors for short-lived U-series nuclides are also obtained by comparing their activities with the ${ }^{222} \mathrm{Rn}$ activities, indicative of the supply rate of short-lived nuclides in the ${ }^{238} U$ decay series due to recoil related effects (1). In addition, some samples in the UZ have values of $\left.\left.R_{f}{ }^{226} R a\right) / R_{f}{ }^{238} U\right)$ near 0.01, indicating that for these samples $R_{f}\left({ }^{238} U\right)>100$, since $\left.R_{f}{ }^{226} R a\right)$ must be $>1$.

Ranges of retardation factors for the SZ are $\sim 10$ to 10,000 for ${ }^{238} \mathrm{U}$ and ${ }^{226} \mathrm{Ra}$, $\sim 1000$ to $10,000,000$ for ${ }^{230} \mathrm{Th}$, and $>34,000$ for ${ }^{239} \mathrm{Pu}$. However, using the average value of 1300 for $\left.\mathrm{R}_{\mathrm{f}}{ }^{238} \mathrm{U}\right)$ in the $\mathrm{SZ}$, the retardation factor for ${ }^{239} \mathrm{Pu}$ in the SZ is likely to be $>1,000,000$. Based on the data in Table S4 and Fig. 6, average values of SZ retardation factors range from $10^{3}$ to $10^{7}$, and decrease in the order ${ }^{239} \mathrm{Pu}{ }^{210} \mathrm{Po} \sim{ }^{230} \mathrm{Th}>{ }^{210} \mathrm{~Pb}>{ }^{238} \mathrm{U}{ }^{226} \mathrm{Ra}$. 
Using the average value of 1300 for $\mathrm{R}_{\mathrm{f}}\left({ }^{238} \mathrm{U}\right)$ in the $\mathrm{SZ}$, absolute retardation factors for U-series daughter nuclides in the UZ range from $\sim 10$ to 230 for ${ }^{226} \mathrm{Ra}$ and from $\sim 1300$ to 260,000 for ${ }^{230} \mathrm{Th}$ based on samples from the mine adit. Both ${ }^{226} \mathrm{Ra}$ and ${ }^{230} \mathrm{Th}$ have greater mobility in the UZ near the ore deposit than the SZ. Greater UZ mobility for these nuclides is an unusual characteristic which may be related to higher sulfate concentrations for the UZ and near-field SZ relative to the far-field SZ (21). Greater mobility does not persist into the SZ, where retardation factors return to high values more typical of groundwater systems in general (e.g. 1-3).

Our results on U-series nuclide mobility at Peña Blanca can be compared to sorption data for Yucca Mountain tuff obtained from laboratory experiments (22). In general, $\mathrm{K}_{\mathrm{d}}$ values for $\mathrm{U}=2$ $20 \mathrm{~mL} / \mathrm{g}$, for $\mathrm{Ra}$ and $\mathrm{Th}=100-10,000 \mathrm{~mL} / \mathrm{g}$, and for $\mathrm{Pu}=10-10,000 \mathrm{~mL} / \mathrm{g}$. Based on the porosity and bulk density of the Yucca Mountain tuffs, retardation factors are a factor of $~ 10$ larger than the $\mathrm{K}_{\mathrm{d}}$ values. Results presented here are consistent with some of these trends, but not all of them. Most notably, Yucca Mountain sorption data indicate that Ra should be retarded much more strongly than U. Since Ra mobility in the SZ at Peña Blanca is typical of groundwater in general, the major difference in the data sets for the SZ appears to be related to $\mathrm{U}$ mobility. Namely, U mobility appears to be a factor of 10-100 higher in the sorption data set relative to in-situ U-series measurements performed at Peña Blanca and other sites (2).

In order to define the uranium colloidal contribution, two SZ samples (PB1 and PB4) have been ultrafiltered in the laboratory. Uranium concentration measurements (Table S3) indicate that $\sim 93-97 \%$ of uranium present is truly dissolved. Similar ${ }^{234} U /{ }^{238} U$ for unfiltered, filtered ( $<200$ $\mathrm{nm})$, and ultrafiltered $(<20-\mathrm{nm})$ aliquots also support this conclusion. These results are similar to 
prior studies for other uranium deposits such as Koongarra (23), which indicate $~ 3 \%$ of uranium occurs as colloids. These results also agree with results for groundwater from the Nevada Test Site (24). However, the small fraction of colloidal uranium could have environmental implications in some cases, as it can migrate in subsurface media much faster and can travel distances much larger than dissolved uranium (e.g. 25). This may be due to the presence of small quantities of highly mobile colloids in the colloid population (26).

To summarize, our U-series results provide initial field data on uranium dissolution inputs ( $~ 1$ ppb dissolved U/day) in the UZ. At Peña Blanca, our U concentration data suggest that SZ groundwater flow rates are slow $(\sim 10 \mathrm{~m} / \mathrm{y})$. We also obtained initial constraints on ${ }^{238} \mathrm{U}_{-}^{239} \mathrm{Pu}$ disequilibrium in the SZ, with Pu mobility $>1000$ times lower than the U mobility. Radionuclide transport rates in the SZ are, on average, factors of $10^{3}$ to $10^{7}$ lower than the groundwater flow rate and decrease in the order ${ }^{226} \mathrm{Ra}^{238} \mathrm{U}>{ }^{239} \mathrm{Pu} \sim{ }^{230} \mathrm{Th}$. Both $\mathrm{Ra}$ and Th appear to have on average greater mobility $(\sim \times 10)$ in the UZ than the SZ.

\section{Acknowledgments}

We thank Ignacio Reyes and Rodrigo de la Garza (Universidad Autónoma de Chihuahua), Alfredo Rodríguez (WWF), Paul Cook and Teamrat Ghezzehei (LBNL), and Paul Reimus, John Dinsmoor, and Ron Oliver (LANL) for valuable discussions and assistance in the field. We also thank Ardyth Simmons and Schon Levy (LANL) for project guidance. Finally, we thank the anonymous ES\&T reviewers for helpful comments. 
This work was supported by the U.S. DOE, Office of Civilian Radioactive Waste Management (OCRWM), under contract DE-AC02-05CH11231. The views expressed in this article are those of the authors and do not necessarily reflect the views or policies of the United States Department of Energy or OCRWM.

The United States Government retains and the publisher, by accepting the article for publication, acknowledges that the United States Government retains a non-exclusive, paid-up, irrevocable, world-wide license to publish or reproduce the published form of this manuscript, or allow others to do so, for United States Government purposes.

Brief - Groundwater uranium-series measurements near an ore deposit constrain hydrologic and radionuclide transport rates in a similar setting to the proposed U.S. high-level nuclear waste repository.

\section{Supporting Information -}

Table S1. Groundwater well uranium concentrations and ${ }^{234} \mathrm{U} /{ }^{238} \mathrm{U}$ activity ratios measured by isotope dilution mass spectrometry for samples collected in 2003-2006.

Table S2. Uranium concentrations and ${ }^{234} \mathrm{U} /{ }^{238} \mathrm{U}$ activity ratios for unsaturated zone samples collected from the mine adit in 2003-2006 measured by isotope dilution mass spectrometry.

Table S3. Comparison of uranium concentrations and ${ }^{234} \mathrm{U} /{ }^{238} \mathrm{U}$ ratios for unfiltered samples, samples filtered in the field, and ultrafiltered samples.

Table S4. Estimated retardation factors for various U-series nuclides for saturated and unsaturated zone samples. 


\section{References}

(1) Krishnaswami, S; Graustein, W.C.; Turekian, K.K.; Dowd, J.F. Radium, thorium and radioactive lead isotopes in groundwaters: application to the in situ determination of adsorptiondesorption rate constants and retardation factors. Water Resour. Res. 1982, 6, 1663-1675.

(2) Luo, S.; Ku, T.L.; Roback, R.; Murrell, M.; McLing, T.L. In-situ radionuclide transport and preferential groundwater flows at INEEL (Idaho): Decay-series disequilibrium studies. Geochim. Cosmochim. Acta 2000, 64, 867-881.

(3) Porcelli, D.; Swarzenski, P.W. The behavior of U- and Th-series nuclides in groundwater. Rev. Mineral. Geochem. 2003, 52, 317-361.

(4) Pearcy, E.C.; Prikryl, J.D.; Murphy, W.M.; Leslie, B.W. Alteration of uraninite from the Nopal I deposit, Peña Blanca district, Chihuahua, Mexico, compared to degradation of spent nuclear fuel in the proposed US high-level nuclear waste repository at Yucca Mountain, Nevada. Appl. Geochem. 1994, 9, 713-732.

(5) Wronkiewicz, D.J.; Bates, J.K.; Wolf, S.F.; Buck, E.C. Ten-year results from unsaturated drip tests with $\mathrm{UO}_{2}$ at $90^{\circ} \mathrm{C}$ : Implications for the corrosion of spent nuclear fuel. Journal of Nuclear Materials 1996, 238, 78-95.

(6) Dobson, P.F.; Fayek, M.; Goodell, P.C.; Ghezzehei, T.A.; Melchor, F.; Murrell, M.T.;

Oliver, R.; Reyes-Cortés, I.A.; de la Garza, R; Simmons, A. Stratigraphy of the PB-1 well, Nopal I uranium deposit, Sierra Peña Blanca, Chihuahua, Mexico. International Geology Review 2008, 50, 959-974. 
(7) Goldstein, S.J.; Murrell, M.T.; Janecky, D.R., Th and U isotopic systematic of basalts from the Juan de Fuca and Gorda ridges by mass spectrometry. Earth Planet. Sci. Lett. 1989, 96, 134146.

(8) Volpe, A.M.; Olivares, J.A.; Murrell, M.T., Determination of radium isotope ratios and abundances in geologic samples by thermal ionization mass spectrometry. Anal. Chem. 1991, 63, 913-916.

(9) Oliver, R.D.; Dinsmoor, J.C.; Goldstein, S.J.; Reyes-Cortés, I.A.; de la Garza, R. Initial test well conditioning at Nopal I uranium deposit, Sierra Peña Blanca, Chihuahua, Mexico. Geol. Soc. Amer. Abstracts with Programs 2005, 37 (7), 197.

(10) Villalba, M.L.; Colmenero-Sujo, L.H.; Motero-Cabrera, M.E.; Manjon, G.; ChavesAguirre, R.; Royo-Ochoa, M.; Pinales-Munguia, A. Presence of uranium in the Río Chuvíscar, state of Chihuahua, México. GEOS 2006, 25, 363-367.

(11) Drost, W.; Klotz, D.; Koch, A.; Moser, H.; Neumaier, F.; Rauert, W. Point dilution methods of investigating ground water flow by means of radioisotopes. Water Resour. Res. 1968, 4, 125-146.

(12) Luo, S.; Ku, T.; Todd, V.; Murrell, M.T.; Dinsmoor, J.C. Increased concentrations of short-lived decay-series radionuclides in groundwaters underneath the Nopal I uranium deposit at Pena Blanca, Mexico. Eos Trans. AGU 2007, 88(23), GS22A-03.

(13) Pickett D.A.; Murphy, W.M. Unsaturated zone waters from the Nopal I natural analog, Chihuahua, Mexico - implications for radionuclide mobility at Yucca Mountain. In Scientific Basis for Nuclear Waste Management XXII; D.J. Wronkiewicz and J. Lee, Eds.; Materials Research Society: Warrendale, Pennsylvania 1999, pp. 809-816. 
(14) Ku, T.L.; Luo, S.; Goldstein, S.J.; Murrell, M.T.; Chu, W.L.; Dobson, P.F. Modeling nonsteady state radioisotope transport in the vadose zone - a case study using uranium isotopes at Peña Blanca, Mexico. Geochim. Cosmochim. Acta 2009, 73, 6052-6064.

(15) Paces, J.B.; Ludwig, K.R.; Peterman, Z.E.; Neymark, L.A., ${ }^{234} U /{ }^{238} U$ evidence for local recharge and patterns of groundwater flow in the vicinity of Yucca Mountain, Nevada, USA. Appl. Geochem. 2002, 17, 751-779.

(16) Delemos, J.L.; Bostick, B.C.; Quicksall, A.N., Landis, J.D.; George, C.C.; Slagowski, N.L.; Rock, T.; Brugge, D.; Lewis, J.; Durant, J.L. Rapid dissolution of soluble uranyl phases in arid, mine-impacted catchments near Church Rock, NM. Environ. Sci. Technol. 2008, 42, 3951-3957. (17) Fayek, M.; Ren, M.; Goodell, P.; Dobson, P.; Saucedo, A.; Kelts, A.; Utsunomiya, S.; Ewing, R.C.; Riciputi, L.R.; Reyes, I. Petrogenesis and geochronology of the Nopal I uranium deposit, Mexico. In Proceedings, 2006 International High Level Radioactive Waste Management Conference; American Nuclear Society: Las Vegas 2006, pp. 55-62.

(18) Murrell, M.T.; Goldstein, S.J.; Dixon, P.R. Uranium decay series mobility at Peña Blanca, Mexico, implications for nuclear repository stability. In Eighth EC Natural Analogue Working Group Meeting; H. von Maravic and W.R. Alexander, Eds.; European Commission Nuclear Science and Technology (EUR 19118) 2002, pp. 339-347.

(19) Leslie, B.W.; Pickett, D.A.; Pearcy, E.C. Vegetation-derived insights on the mobilization and potential transport of radionuclides from the Nopal I natural analog site, Mexico. In Scientific Basis for Nuclear Waste Management XXII; D.J. Wronkiewicz and J. Lee, Eds.; Materials Research Society: Warrendale, Pennsylvania 1999, pp. 833-842.

(20) Curtis, D.; Fabryka-Martin, J.; Dixon, P.; Cramer, J. Nature's uncommon elements: plutonium and technetium. Geochim. Cosmochim. Acta 1999, 63, 275-285. 
(21) Natural analogue synthesis report; Report TDR-NBS-GS-000027 REV01; Civilian Radioactive Waste Management System Management \& Operating Contractor; www.lsnnet.gov. (22) Site-scale saturated zone transport; Report MDL-NBS-HS-000010 REV03; Sandia National Laboratories: Albuquerque, New Mexico, 2007; www.lsnnet.gov.

(23) Payne, T.E.; Airey, P.L. Radionuclide migration at the Koongarra uranium deposit, Northern Australia - lessons from the Alligator Rivers analogue project. Physics and Chemistry of the Earth 2006, 31, 572-586.

(24) Abdel-Fattah, Amr I.; Smith, D.; Murrell, M.; Goldstein, S.; Nunn, A.; Gritzo, R.; Martinez, B.; Reimus, P. Colloid characterization and radionuclide associations with colloids in sourceterm waters at the Nevada Test Site. Los Alamos National Laboratory Report LA-UR-05-5312: Los Alamos, New Mexico, 2005.

(25) Kersting, A.B.; Efurd, D.W.; Finnegan, D.L.; Rokop, D.J.; Smith, D.K.; Thompson, J.L. Migration of plutonium in groundwater at the Nevada Test Site, Nature 1999, 397, 56-59.

(26) Robinson , B.A.; Wolfsberg, A.V.; Viswanathan, H.S.; Reimus, P.W. A colloid-facilitated transport model with variable colloid transport properties. Geophys. Res. Lett. 2007, 34, L09401. 
Table 1. U-Th-Ra disequilibria systematics for unsaturated and saturated zone water samples collected in 2000 -2001 measured by isotope dilution mass spectrometry.

\begin{tabular}{|c|c|c|c|c|c|c|c|c|c|c|}
\hline Location & Sample ID & $\begin{array}{l}\text { Date } \\
\text { Collected }\end{array}$ & $\begin{array}{l}\text { [U] } \\
\text { (ng/g) }\end{array}$ & $\begin{array}{l}{ }^{234} \mathrm{U} /{ }^{238} \mathrm{U} \\
\text { (activity } \\
\text { ratio) }\end{array}$ & $\begin{array}{l}\text { Thh] } \\
\text { (pg/g) }\end{array}$ & $\begin{array}{l}{\left[{ }^{230} \mathrm{Th}\right]} \\
\text { (fg/g) }\end{array}$ & $\begin{array}{l}{ }^{230} \mathrm{Th} /{ }^{234} \mathrm{U} \\
\text { (activity } \\
\text { ratio) }\end{array}$ & $\begin{array}{l}{\left[{ }^{226} \mathrm{Ra}\right]} \\
\text { (fg/g) }\end{array}$ & $\begin{array}{l}{ }^{226} \mathrm{Ra} /{ }^{230} \mathrm{Th} \\
\text { (activity } \\
\text { ratio) }\end{array}$ & $\begin{array}{l}{ }^{226} \mathrm{Ra} /{ }^{238} \mathrm{U} \\
\text { (activity } \\
\text { ratio) }\end{array}$ \\
\hline \multicolumn{11}{|l|}{$\begin{array}{l}\text { Unsaturated } \\
\text { Zone: }\end{array}$} \\
\hline $\begin{array}{l}\text { Perched water } \\
\text { from borehole } \\
\text { at }+10 \text { level }\end{array}$ & AS-5 & 25-Feb-00 & $\begin{array}{l}5.734+/- \\
0.011\end{array}$ & $\begin{array}{l}2.856+/- \\
0.003\end{array}$ & $\begin{array}{l}136.7+/- \\
0.4\end{array}$ & $\begin{array}{l}3.11+/- \\
0.03\end{array}$ & $\begin{array}{l}0.0116+/- \\
0.0001\end{array}$ & & & \\
\hline $\begin{array}{l}\text { Perched water } \\
\text { from borehole } \\
\text { at }+10 \text { level }\end{array}$ & 030701-01 & 7-Mar-01 & $\begin{array}{l}10.40+/- \\
0.002\end{array}$ & $\begin{array}{l}2.051+/- \\
0.002\end{array}$ & & & & $\begin{array}{l}0.022+/- \\
0.001\end{array}$ & & $\begin{array}{l}0.0062+/- \\
0.0002\end{array}$ \\
\hline $\begin{array}{l}\text { Front of Adit } \\
\text { near UACH } 1 \mathrm{a}\end{array}$ & 030701-05 & 7-Mar-01 & $\begin{array}{l}13.01+/- \\
0.03\end{array}$ & $\begin{array}{l}1.023+/- \\
0.002\end{array}$ & $\begin{array}{l}17.13+/- \\
0.13\end{array}$ & $\begin{array}{l}76.1+/- \\
0.2\end{array}$ & $\begin{array}{l}0.349+/- \\
0.002\end{array}$ & $\begin{array}{l}54.3+/- \\
0.3\end{array}$ & $34.4+/-0.2$ & $\begin{array}{l}12.4+/- \\
0.1\end{array}$ \\
\hline $\begin{array}{l}\text { Front of Adit } \\
\text { near UACH } 3\end{array}$ & AS-1 & 25-Feb-00 & $\begin{array}{l}68.46+/- \\
0.13\end{array}$ & $\begin{array}{l}1.060+/- \\
0.001\end{array}$ & $\begin{array}{l}8.76+/- \\
0.06\end{array}$ & $\begin{array}{l}87.7+/- \\
0.5\end{array}$ & $\begin{array}{l}0.0737+/- \\
0.0005\end{array}$ & $194+/-5$ & $106+/-2$ & $\begin{array}{l}8.38+/- \\
0.19\end{array}$ \\
\hline $\begin{array}{l}\text { Front of Adit } \\
\text { near UACH } 5\end{array}$ & AS-2 & 25-Feb-00 & $\begin{array}{l}36.92+/- \\
0.07\end{array}$ & $\begin{array}{l}0.939+/- \\
0.002\end{array}$ & $\begin{array}{l}6.72+/- \\
0.04\end{array}$ & $\begin{array}{l}5.29+/- \\
0.03\end{array}$ & $\begin{array}{l}0.00930+/- \\
0.00006\end{array}$ & $202+/-1$ & $1840+/-10$ & $\begin{array}{l}16.2+/- \\
0.1\end{array}$ \\
\hline $\begin{array}{l}\text { Front of Adit } \\
\text { near UACH } 5\end{array}$ & 030701-04 & 7-Mar-01 & $\begin{array}{l}16.49+/- \\
0.05\end{array}$ & $\begin{array}{l}0.920+/- \\
0.004\end{array}$ & $\begin{array}{l}0.725+/- \\
0.003\end{array}$ & $\begin{array}{l}42.8+/- \\
0.1\end{array}$ & $\begin{array}{l}0.172+/- \\
0.001\end{array}$ & $>20$ & $>20$ & $>3$ \\
\hline $\begin{array}{l}\text { Middle of Adit } \\
\text { near UACH } 7\end{array}$ & AS-3 & 25-Feb-00 & $\begin{array}{l}4.035+/- \\
0.008\end{array}$ & $\begin{array}{l}1.177+/- \\
0.002\end{array}$ & $\begin{array}{l}0.73+/- \\
0.07\end{array}$ & $\begin{array}{l}0.59+/- \\
0.02\end{array}$ & $\begin{array}{l}0.0075+/- \\
0.0003 \\
\end{array}$ & $76+/-6$ & $\begin{array}{l}6200+/- \\
600\end{array}$ & $56+/-4$ \\
\hline $\begin{array}{l}\text { Middle of Adit } \\
\text { near UACH } 7\end{array}$ & 030701-03 & 7-Mar-01 & $\begin{array}{l}26.96+/- \\
0.05\end{array}$ & $\begin{array}{l}1.173+/- \\
0.001\end{array}$ & $\begin{array}{l}0.66+/- \\
0.03\end{array}$ & $\begin{array}{l}2.23+/- \\
0.01\end{array}$ & $\begin{array}{l}0.00429+/- \\
0.00003\end{array}$ & $>470$ & $>10000$ & $>50$ \\
\hline $\begin{array}{l}\text { Back of Adit } \\
\text { near UACH } 9\end{array}$ & AS-4 & 25-Feb-00 & $\begin{array}{l}2.872+/- \\
0.009\end{array}$ & $\begin{array}{l}2.207+/- \\
0.006\end{array}$ & $\begin{array}{l}1.47+/- \\
0.03\end{array}$ & $\begin{array}{l}1.57+/- \\
0.01\end{array}$ & $\begin{array}{l}0.0151+/- \\
0.0001\end{array}$ & $\begin{array}{l}5.51+/- \\
0.04\end{array}$ & $169+/-2$ & $\begin{array}{l}5.68+/- \\
0.05 \\
\end{array}$ \\
\hline $\begin{array}{l}\text { Back of Adit } \\
\text { near UACH } 9\end{array}$ & 030701-02 & 7-Mar-01 & $\begin{array}{l}1.201+/- \\
0.003\end{array}$ & $\begin{array}{l}2.588+/- \\
0.005\end{array}$ & $\begin{array}{l}19.0+/- \\
0.5\end{array}$ & $\begin{array}{l}18.8+/- \\
0.2\end{array}$ & $\begin{array}{l}0.370+/- \\
0.003\end{array}$ & $\begin{array}{l}46.0+/- \\
0.6\end{array}$ & $117+/-2$ & $113+/-2$ \\
\hline \multicolumn{11}{|l|}{$\begin{array}{l}\text { Saturated } \\
\text { Zone: }\end{array}$} \\
\hline PB4 & AS-6 & 25-Feb-00 & $\begin{array}{l}2.528+/- \\
0.006\end{array}$ & $\begin{array}{l}1.183+/- \\
0.003\end{array}$ & $604+/-2$ & $\begin{array}{l}19.7+/- \\
0.1\end{array}$ & $\begin{array}{l}0.402+/- \\
0.003\end{array}$ & & & \\
\hline Pozos Ranch & 030701-06 & 7-Mar-01 & $\begin{array}{l}5.711+/- \\
0.011\end{array}$ & $\begin{array}{l}2.035+/- \\
0.002\end{array}$ & $<0.07$ & & & $\begin{array}{l}0.124+/- \\
0.003\end{array}$ & & $\begin{array}{l}0.0641+/- \\
0.0014\end{array}$ \\
\hline
\end{tabular}

Half-lives used are $4.468 \times 10^{9}$ yr for ${ }^{238} \mathrm{U}, 245250 \mathrm{yr}$ for ${ }^{234} \mathrm{U}, 75690 \mathrm{yr}$ for ${ }^{230} \mathrm{Th}$, and $1600 \mathrm{yr}$ for ${ }^{226} \mathrm{Ra}$. 


\section{Figure Captions:}

Fig. 1. A) General location of study area. Assumed direction of groundwater flow is from the west to the east from the Sierra Peña Blanca toward the Playa Cuervo. Bosque near Aldama is the location of sampling of the Chuviscar River by Villalba et al (10). B) Location of wells in this study. Base map taken from Instituto de Estadística, Geografía e Informática 1:50,000 El Sauz topographic map (H13C46).

Fig. 2. A) Schematic map of the UACH (Universidad Autónoma de Chihuahua) and LBNL (Lawrence Berkeley National Laboratory) unsaturated zone sample collection sites from the mine adit located on the +00 level. The collectors consisted of plastic sheeting which was designed to funnel seepage water into plastic bottles (blue boxes; UACH), or a fine grid of hard plastic collectors and bottles (red outlined boxes; LBNL). The LBNL collectors replaced the UACH collectors in 2005. Locations of the UACH collectors are approximate only. B) Photo of the array of LBNL seepage collectors along with a column equipped with transducers to measure the timing and volume of seepage events.

Fig. 3. Time-series of uranium concentrations in saturated zone groundwater samples near Peña Blanca. Uranium concentrations in wells drilled in 2003 (PB1, PB2, PB3) have generally exponentially decreased over time, although well pumping and conditioning in December 2003 and August 2006 disturbed the trend. Results for PB4, Peña Blanca Ranch, and Pozos Ranch have remained low over this time period. Results for December 2006 are from M. Rearick (LANL, personal communication). 
Fig. 4. Uranium isotope mixing diagram for groundwater samples from the saturated zone. Data with $1 /[\mathrm{U}]>1$ not shown. At least three components for uranium (denoted by stars) with limited mixing between these components are indicated. An exception to this is the results for PB1 and PB2, which along with well pumping and conditioning results suggest interconnectivity between the groundwater in these two wells. See text for further discussion.

Fig. 5. Uranium isotope mixing diagram for the adit water samples from the unsaturated zone. Data are from this study and Pickett and Murphy (13). Data with 1/[U] $>5$ not shown. A spatial dependence for the uranium isotopic systematics is indicated, and a weak seasonal dependence may also be present (14). Based on a linear approximation for each region of the adit, low intercept and high slope for samples from the front and middle adit are indicative of high uranium dissolution inputs and long water-rock interaction times. Samples from the back adit have experienced lower uranium dissolution inputs and variable but generally shorter water-rock interaction times.

Fig. 6. Graphical representation of the average and range of estimated retardation factors determined from U-series disequilibria for various U-series nuclides in the SZ and UZ. Average values of SZ retardation factors range from $10^{3}$ to $10^{7}$, and decrease in the order ${ }^{239} \mathrm{Pu} \sim{ }^{210} \mathrm{Po} \sim{ }^{230} \mathrm{Th}>{ }^{210} \mathrm{~Pb}>{ }^{238} \mathrm{U} \sim{ }^{226} \mathrm{Ra}$. Both ${ }^{230} \mathrm{Th}$ and ${ }^{226} \mathrm{Ra}$ appear to have greater mobility in the UZ than the SZ. Results are from this study and Luo et al. (12). 
Figure 1: A)

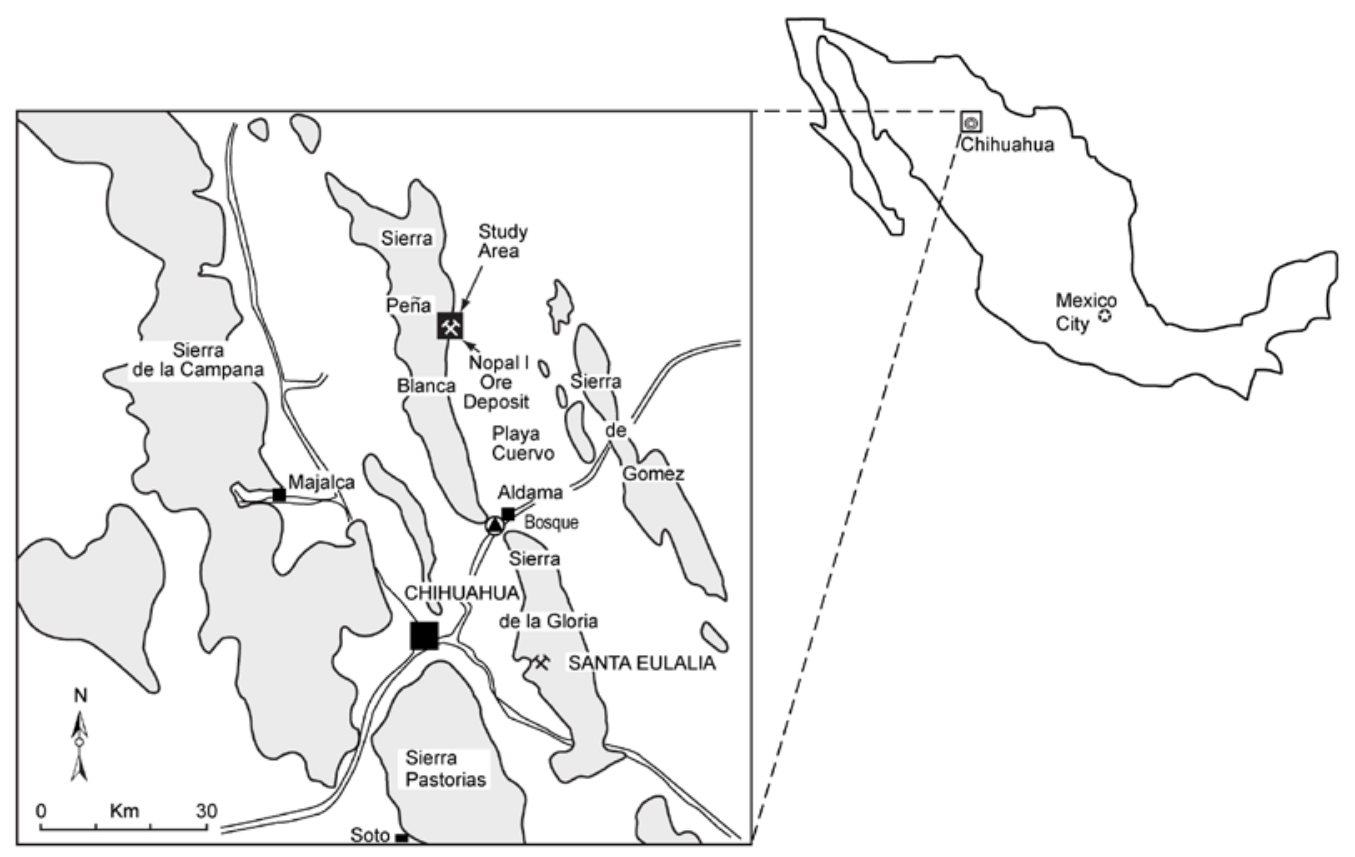


Figure 1: B)

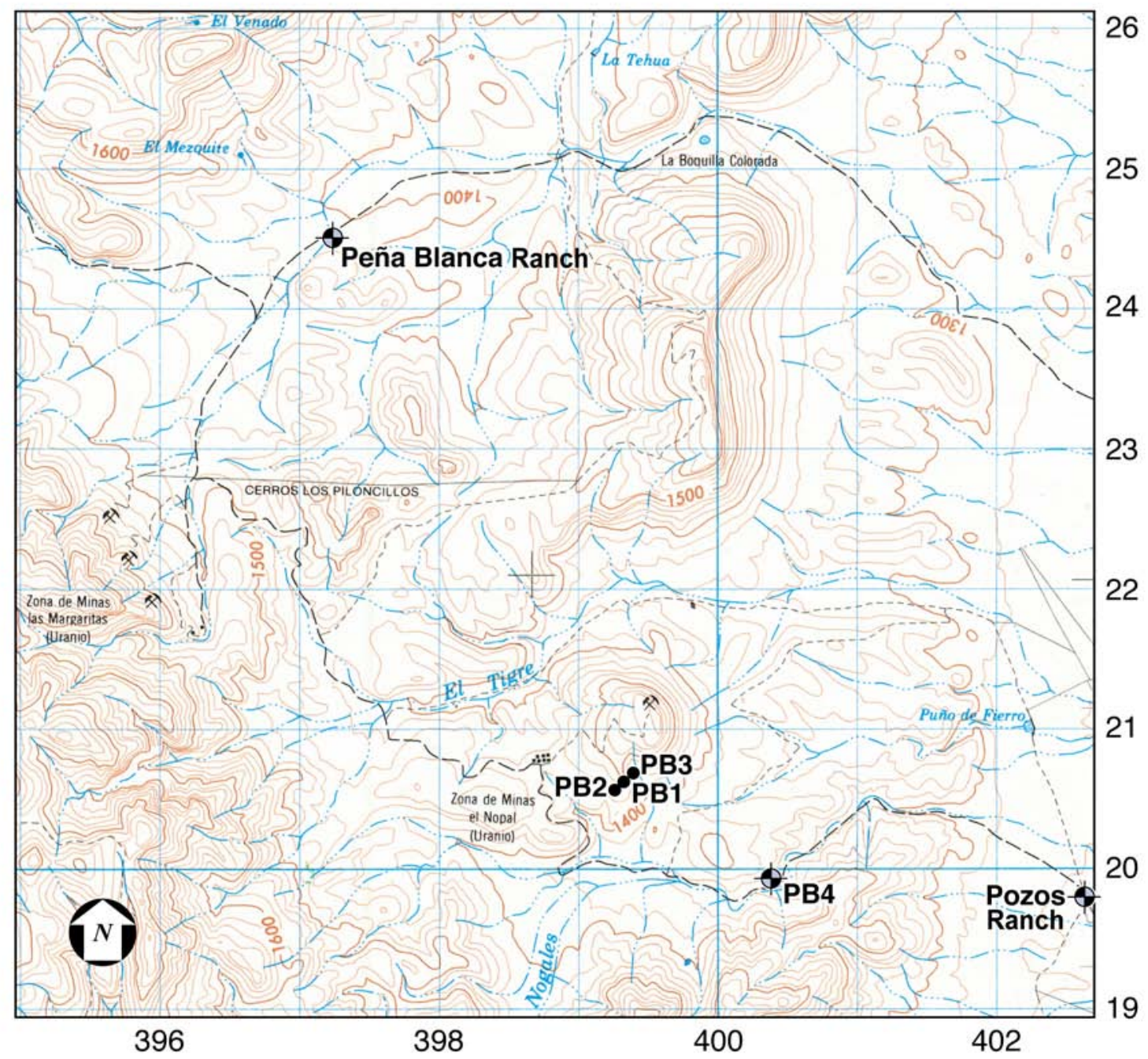

\section{Legend}

Existing Wells

- New Peña Blanca Boreholes

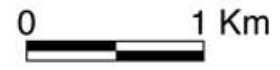

Contour Interval $=20$ Meters 
Figure 2: A)

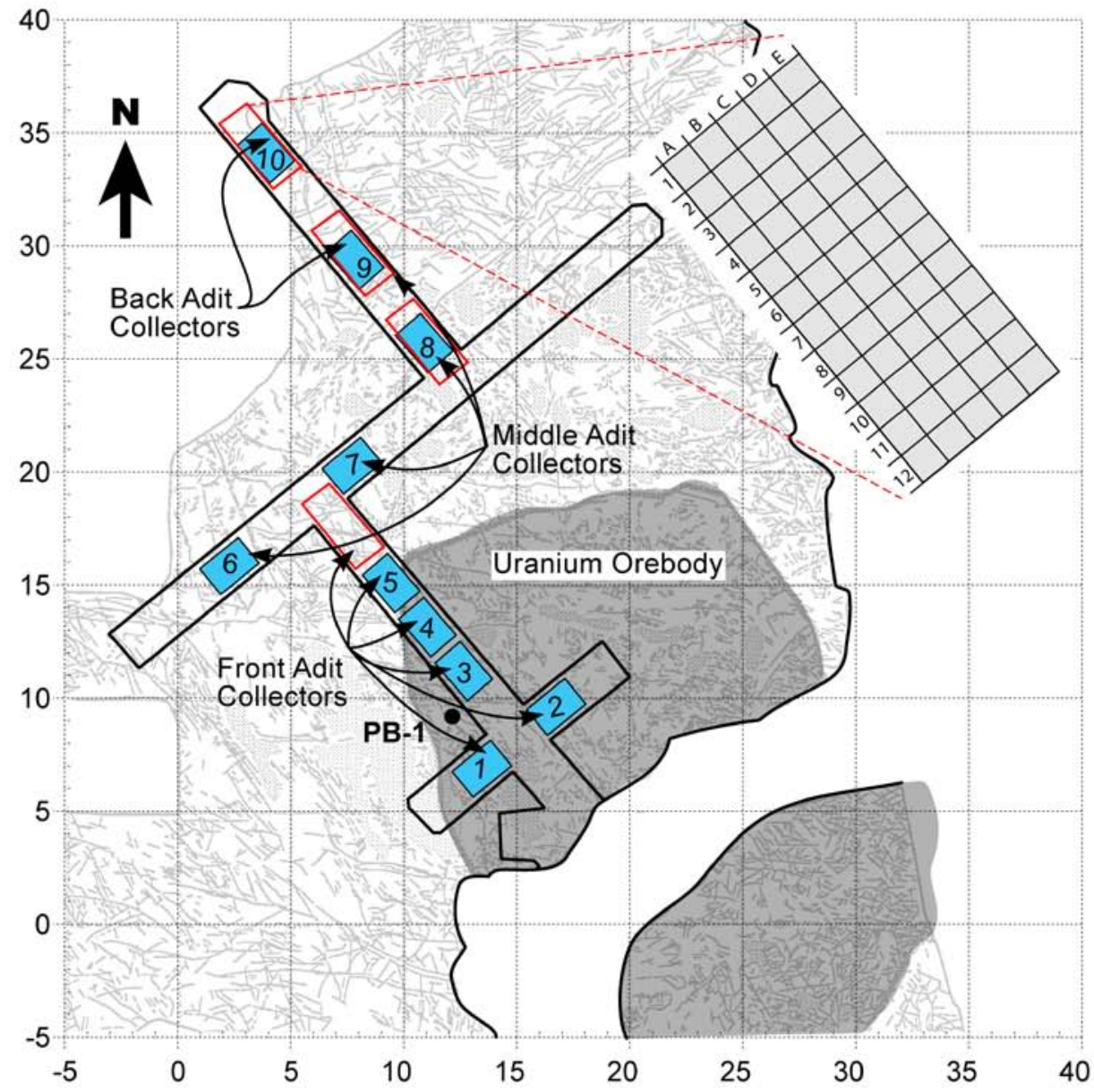


Figure 2: B)

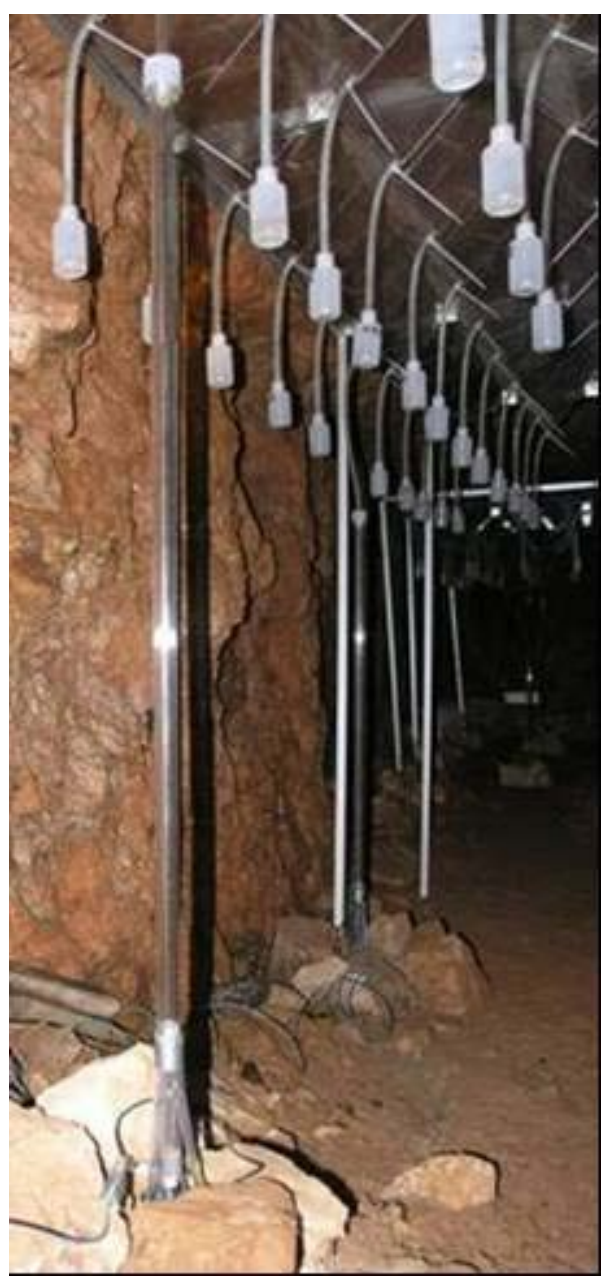


Figure 3:

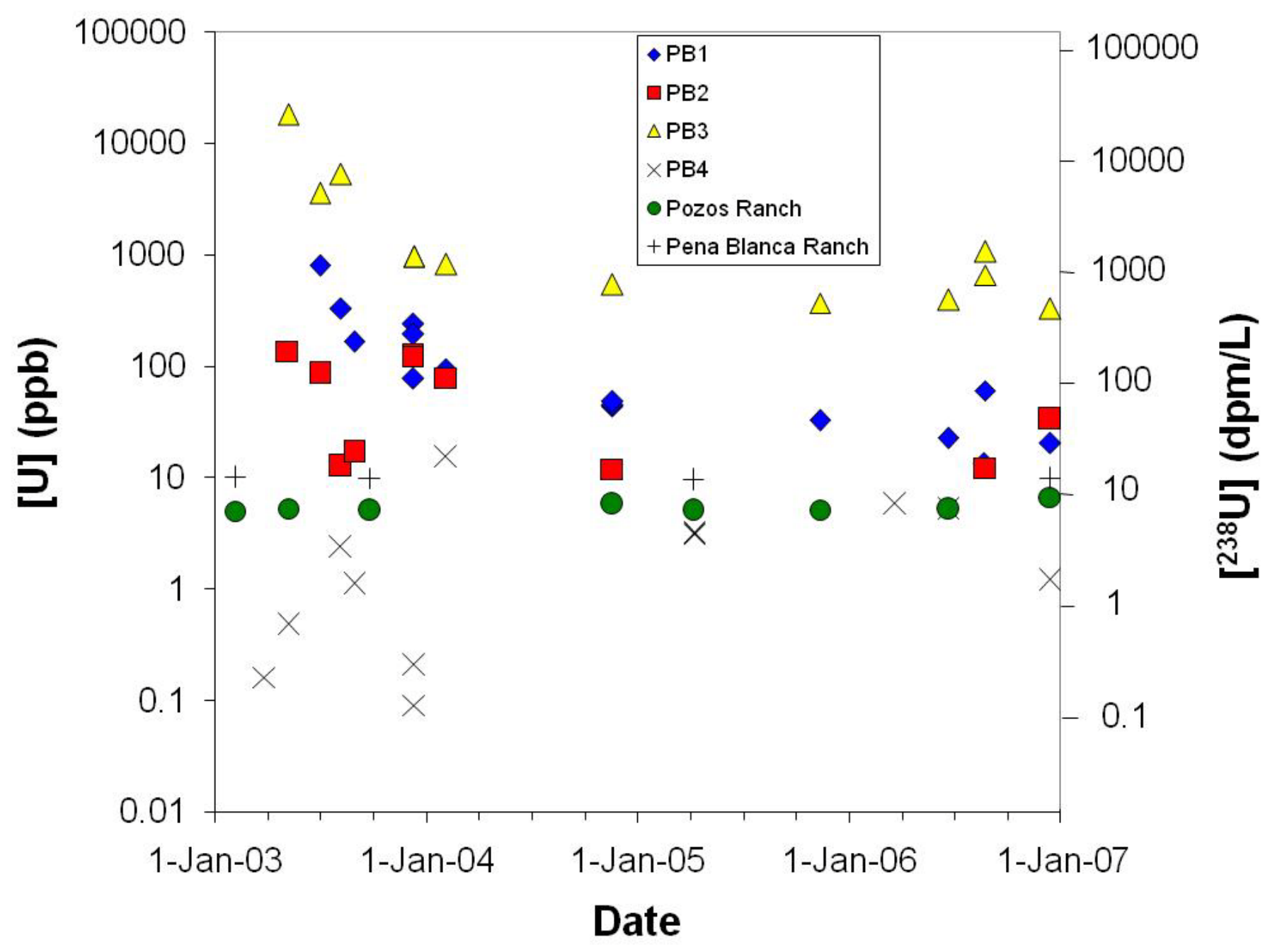


Figure 4:

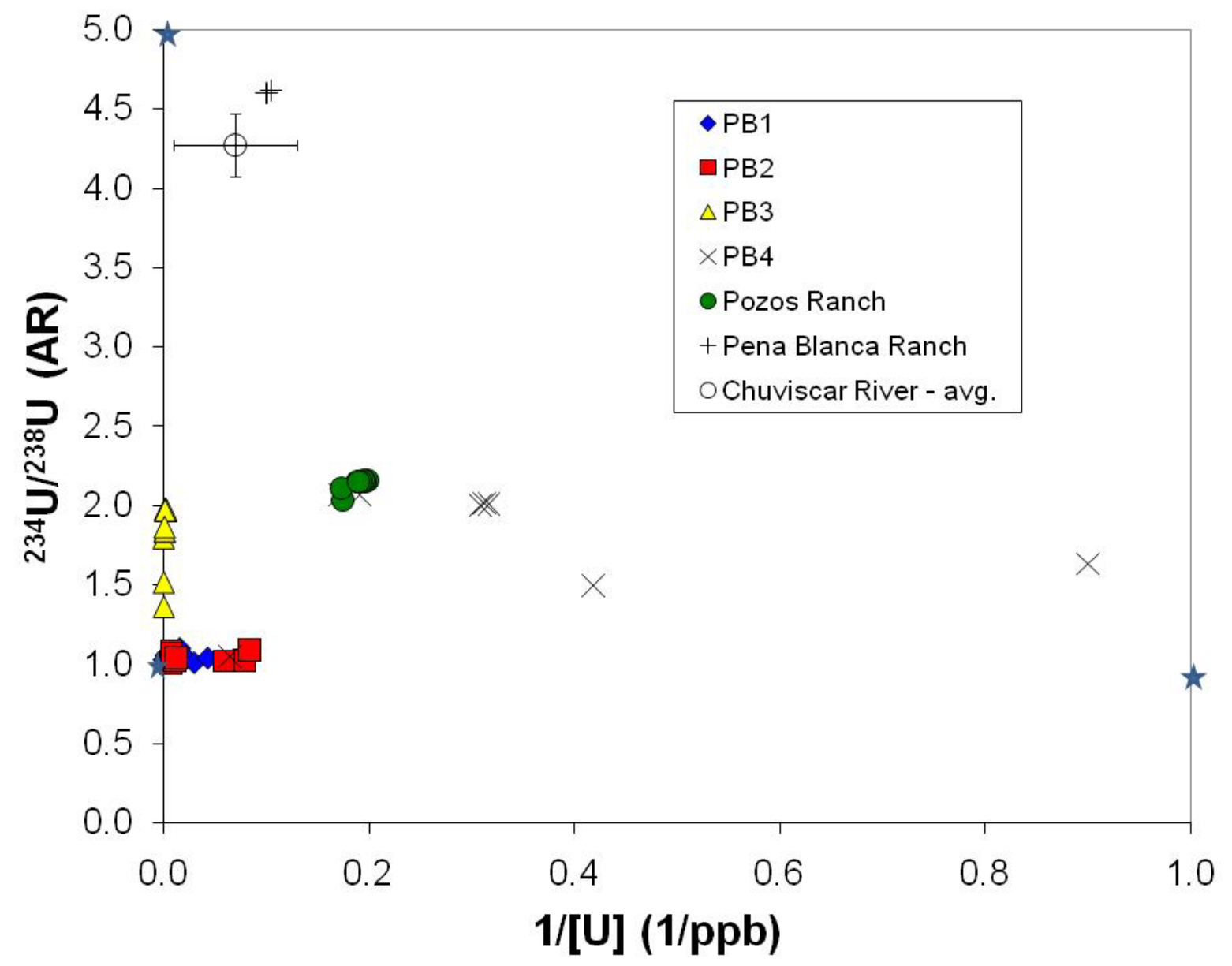


Figure 5:

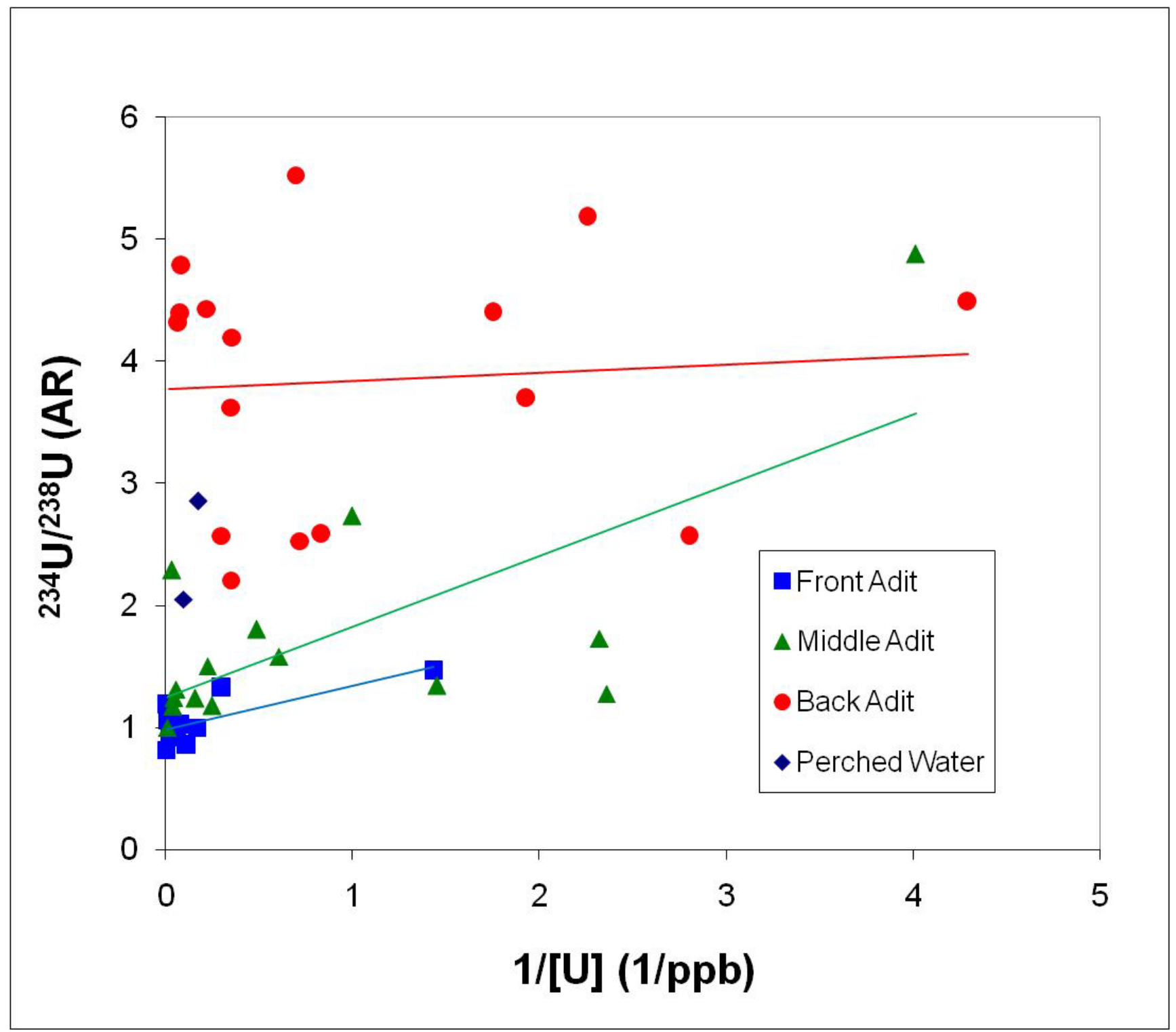


Figure 6:

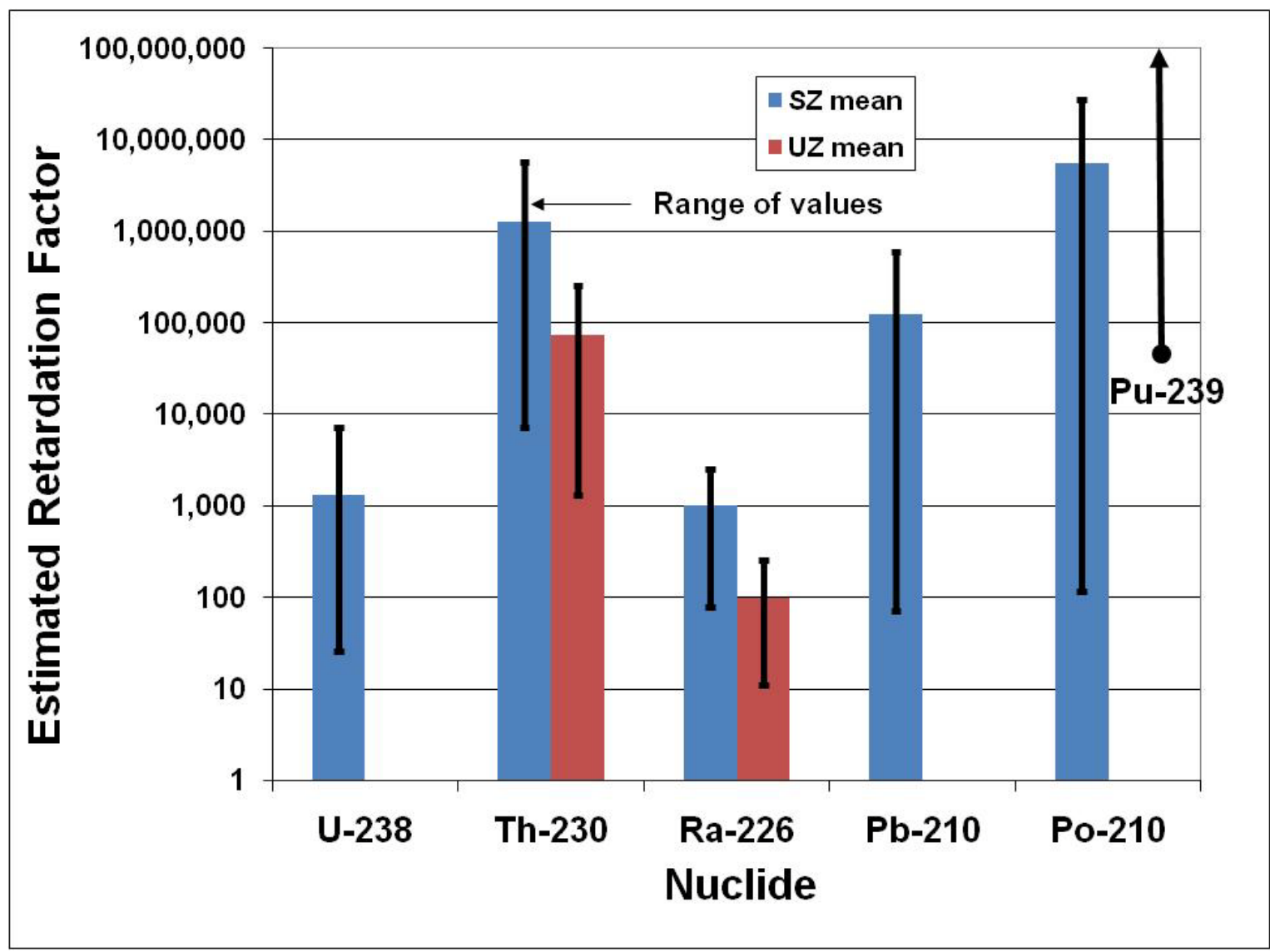


Table S1. Groundwater well uranium concentrations and ${ }^{234} U /{ }^{238} U$ activity ratios measured by isotope dilution mass spectrometry for samples collected in 2003-2006.

\begin{tabular}{|c|c|c|c|c|}
\hline Well & Sample ID & $\begin{array}{l}\text { Date } \\
\text { Collected }\end{array}$ & $\begin{array}{l}\text { [U] } \\
\text { (ng/g) }\end{array}$ & $\begin{array}{l}{ }^{234} \mathrm{U} /{ }^{238} \mathrm{U} \\
\text { (activity ratio) }\end{array}$ \\
\hline \multirow[t]{11}{*}{ PB1 } & SPC1025028 & 1-Jul-03 & 802.3 & 1.029 \\
\hline & SPC1025022 & 6-Aug-03 & 328.0 & 1.058 \\
\hline & SPC1025029 & 29-Aug-03 & 166.5 & 1.021 \\
\hline & SPC1025044 & 9-Dec-03 & 241.4 & 1.011 \\
\hline & SPC1025047 & 9-Dec-03 & 194.9 & 1.028 \\
\hline & SPC1025049 & 9-Dec-03 & 77.69 & 1.050 \\
\hline & SPC1025058 & 5-Feb-04 & 92.96 & 1.006 \\
\hline & SPC1031344 & 17-Nov-04 & 43.88 & 1.044 \\
\hline & SPC1038245 & 11-Nov-05 & 32.82 & 1.010 \\
\hline & SPC2041865 & 21-Jun-06 & 22.91 & 1.040 \\
\hline & SPC1025068 & 23-Aug-06 & 60.68 & 1.102 \\
\hline \multirow[t]{8}{*}{ PB2 } & SPC1025017 & 6-May-03 & 137.2 & 1.005 \\
\hline & SPC1025026 & 1-Jul-03 & 87.28 & 1.019 \\
\hline & SPC1025023 & 6-Aug-03 & 12.67 & 1.025 \\
\hline & SPC1025030 & 29-Aug-03 & 16.94 & 1.019 \\
\hline & SPC1025043 & 8-Dec-03 & 123.9 & 1.079 \\
\hline & SPC1025050 & 8-Dec-03 & 123.4 & 1.065 \\
\hline & SPC1025059 & 5-Feb-04 & 79.16 & 1.039 \\
\hline & SPC1031341 & 17-Nov-04 & 11.91 & 1.090 \\
\hline \multirow[t]{11}{*}{ PB3 } & SPC1025019 & 7-May-03 & 18200 & 1.794 \\
\hline & SPC1025027 & 1-Jul-03 & 3596 & 1.363 \\
\hline & SPC1025024 & 6-Aug-03 & 5343 & 1.516 \\
\hline & SPC1025046 & 10-Dec-03 & 966.5 & 1.835 \\
\hline & SPC1025051 & 10-Dec-03 & 966.2 & 1.837 \\
\hline & SPC1025060 & 5-Feb-04 & 820.6 & 1.974 \\
\hline & SPC1031350 & 17-Nov-04 & 540.6 & 1.969 \\
\hline & SPC1038246 & 11-Nov-05 & 369.9 & 1.966 \\
\hline & SPC2041885 & 22-Jun-06 & 397.6 & 1.973 \\
\hline & SPC1025069 & 24-Aug-06 & 658.6 & 1.966 \\
\hline & SPC1025070 & 24-Aug-06 & 1077 & 1.862 \\
\hline \multirow[t]{10}{*}{ PB4 } & $032703-1$ & 27-Mar-03 & 0.162 & 1.422 \\
\hline & SPC1025020 & 7-May-03 & 0.482 & 1.712 \\
\hline & SPC1025025 & 6-Aug-03 & 2.388 & 1.494 \\
\hline & SPC1025031 & 29-Aug-03 & 1.110 & 1.631 \\
\hline & SPC1025048 & 12-Dec-03 & 0.091 & 1.470 \\
\hline & SPC1025052 & 12-Dec-03 & 0.209 & 1.431 \\
\hline & SPC1025061 & 5-Feb-04 & 15.41 & 1.048 \\
\hline & SPC1031127 & 8-Apr-05 & 3.197 & 2.012 \\
\hline & SPC1040200 & 21-Mar-06 & 5.793 & 2.066 \\
\hline & SPC2041867 & 21-Jun-06 & 5.229 & 2.066 \\
\hline \multirow[t]{7}{*}{ Pozos Ranch } & 020403-1 & 4-Feb-03 & 5.024 & 2.156 \\
\hline & SPC1025021 & 7-May-03 & 5.291 & 2.149 \\
\hline & SPC1025039 & 26-Sep-03 & 5.097 & 2.150 \\
\hline & SPC1031348 & 17-Nov-04 & 5.773 & 2.108 \\
\hline & SPC1031118 & 6-Apr-05 & 5.135 & 2.159 \\
\hline & SPC1038249 & 11-Nov-05 & 5.189 & 2.152 \\
\hline & SPC2041876 & 22-Jun-06 & 5.264 & 2.152 \\
\hline Peña Blanca Ranch & $020403-3$ & 4-Feb-03 & 10.02 & 4.603 \\
\hline
\end{tabular}




\begin{tabular}{|l|l|l|l|l|}
\hline & SPC1025037 & 26-Sep-03 & 9.945 & 4.603 \\
\hline & SPC1031114 & $6-A p r-05$ & 9.538 & 4.616 \\
\hline
\end{tabular}

Typical uncertainties $(2 \sigma)$ are $<0.5 \%$ for $[U]$ and $<0.2 \%$ for ${ }^{234} \mathrm{U}^{238} \mathrm{U}$. Half-lives used are 4.468E9 yr for ${ }^{238} \mathrm{U}$ and $245250 \mathrm{yr}$ for ${ }^{234} \mathrm{U}$. 
Table S2. Uranium concentrations and ${ }^{234} \mathrm{U} /{ }^{238} \mathrm{U}$ activity ratios for unsaturated zone samples collected from the mine adit in 2003-2006 measured by isotope dilution mass spectrometry.

\begin{tabular}{|c|c|c|c|c|}
\hline Location & Sample ID & $\begin{array}{l}\text { Date } \\
\text { Collected }\end{array}$ & $\begin{array}{l}\text { [U] } \\
\text { (ng/g) }\end{array}$ & $\begin{array}{l}{ }^{234} \mathbf{U} /^{238} \mathrm{U} \\
\text { (activity ratio) }\end{array}$ \\
\hline Front of Adit UACH 4 & SPC1025062 & 11-Apr-05 & 6.034 & 0.999 \\
\hline Front of Adit UACH 5 & SPC1025063 & 11-Apr-05 & 3.350 & 1.326 \\
\hline Front of Adit LBNL 39B & SPC1038735 & 11-Jan-06 & 90.76 & 1.186 \\
\hline Front of Adit LBNL 39B & SPC1040975 & 13-Dec-06 & 0.698 & 1.465 \\
\hline Front of Adit LBNL 47E & SPC1038778 & 11-Jan-06 & 422.4 & 0.817 \\
\hline Front of Adit LBNL 47E & SPC1041416 & 13-Dec-06 & 8.819 & 0.854 \\
\hline Middle of Adit UACH 6 & SPC1025066 & 11-Apr-05 & 0.424 & 1.278 \\
\hline Middle of Adit UACH 6 & SPC1038243 & 10-Nov-05 & 0.043 & 1.207 \\
\hline Middle of Adit UACH 7/7a & SPC1025056 & 29-Jan-04 & 17.97 & 1.313 \\
\hline Middle of Adit UACH 7/7a & SPC1025057 & 29-Jan-04 & 85.15 & 0.999 \\
\hline Middle of Adit UACH 8 & SPC1025034 & 1-Jul-03 & 0.249 & 4.879 \\
\hline Middle of Adit UACH 8 & SPC1025035 & 26-Sep-03 & 4.495 & 1.504 \\
\hline Middle of Adit UACH 8 & SPC1025042 & 15-Oct-03 & 29.41 & 2.291 \\
\hline Middle of Adit UACH 8 & SPC1025055 & 29-Jan-04 & 2.050 & 1.804 \\
\hline Middle of Adit UACH 8 & SPC1025064 & 11-Apr-05 & 1.650 & 1.581 \\
\hline Middle of Adit LBNL 23B & SPC1038263 & 10-Jan-06 & 22.42 & 1.242 \\
\hline Middle of Adit LBNL 27C & SPC1038227 & 9-Nov-05 & 6.254 & 1.237 \\
\hline Middle of Adit LBNL 27C & SPC1040246 & 22-Mar-06 & 0.689 & 1.340 \\
\hline Middle of Adit LBNL 32A & SPC1040259 & 22-Mar-06 & 0.431 & 1.730 \\
\hline Middle of Adit LBNL 34E & SPC1040953 & 12-Dec-06 & 1.000 & 2.731 \\
\hline Back of Adit UACH 9 & SPC1025033 & 1-Jul-03 & 0.357 & 2.570 \\
\hline Back of Adit UACH 9 & SPC1025036 & 26-Sep-03 & 2.817 & 4.197 \\
\hline Back of Adit UACH 9 & SPC1025041 & 15-Oct-03 & 0.443 & 5.181 \\
\hline Back of Adit UACH 9 & SPC1025054 & 29-Jan-04 & 0.571 & 4.399 \\
\hline Back of Adit UACH 10 & SPC1025032 & 1-Jul-03 & 2.838 & 3.625 \\
\hline Back of Adit UACH 10 & SPC1025040 & $15-O c t-03$ & 4.517 & 4.431 \\
\hline Back of Adit UACH 10 & SPC1025053 & 29-Jan-04 & 3.349 & 2.573 \\
\hline Back of Adit UACH 10 & SPC1025065 & 11-Apr-05 & 14.93 & 4.315 \\
\hline Back of Adit LBNL 4D & SPC1038005 & 8-Nov-05 & 12.03 & 4.785 \\
\hline Back of Adit LBNL 8B & SPC1037917 & 8-Nov-05 & 12.56 & 4.392 \\
\hline Back of Adit LBNL 11A & SPC1037936 & 8-Nov-05 & 1.439 & 5.526 \\
\hline Back of Adit LBNL 18A & SPC1037978 & 10-Nov-05 & 0.233 & 4.489 \\
\hline Back of Adit LBNL 18A & SPC1038255 & 10-Jan-06 & 0.088 & 2.966 \\
\hline Back of Adit LBNL 18A & SPC1040296 & 23-Mar-06 & 1.385 & 2.528 \\
\hline Back of Adit LBNL 18A & SPC2041957 & 26-Aug-06 & 0.518 & 3.697 \\
\hline
\end{tabular}

Typical uncertainties $(2 \sigma)$ are $<0.5 \%$ for $[U]$ and $<0.2 \%$ for ${ }^{234} \mathrm{U} /{ }^{238} \mathrm{U}$. Half-lives used are 4.468E9 yr for ${ }^{238} \mathrm{U}$ and 245250 yr for ${ }^{234} \mathrm{U}$. 
Table S3. Comparison of uranium concentrations and ${ }^{234} \mathrm{U} /{ }^{238} \mathrm{U}$ ratios for unfiltered samples, samples filtered in the field, and ultrafiltered samples.

\begin{tabular}{|c|c|c|c|c|}
\hline Location - Filtration & Sample ID & $\begin{array}{l}\text { Date } \\
\text { Collected }\end{array}$ & $\begin{array}{l}\text { [U] } \\
\text { (ng/g) }\end{array}$ & $\begin{array}{l}{ }^{234} \mathrm{U} /{ }^{238} \mathrm{U} \\
\text { (activity } \\
\text { ratio) }\end{array}$ \\
\hline PB1 - unfiltered & SPC1031345 & 17-Nov-04 & $\begin{array}{l}48.58+/- \\
0.11\end{array}$ & $\begin{array}{l}0.995+/- \\
0.002\end{array}$ \\
\hline PB1 $-<0.20$ um in field & SPC1031344 & 17-Nov-04 & $\begin{array}{l}43.88+/- \\
0.09\end{array}$ & $\begin{array}{l}1.044+/- \\
0.003\end{array}$ \\
\hline PB1 - ultrafiltered in lab & SPC1031345 & 17-Nov-04 & $\begin{array}{l}45.64+/- \\
0.10\end{array}$ & $\begin{array}{l}1.000+/- \\
0.002\end{array}$ \\
\hline PB4 - unfiltered & SPC1031127 & 8-Apr-05 & $\begin{array}{l}3.237+/- \\
0.007\end{array}$ & $\begin{array}{l}2.002+/- \\
0.003\end{array}$ \\
\hline PB4 - $<0.20$ um in field & SPC1031127 & 8-Apr-05 & $\begin{array}{l}3.197+/- \\
0.007\end{array}$ & $\begin{array}{l}2.012+/- \\
0.003\end{array}$ \\
\hline PB4 - ultrafiltered in lab & SPC1031127 & 8-Apr-05 & $\begin{array}{l}3.152+/- \\
0.007\end{array}$ & $\begin{array}{l}2.009+/- \\
0.003\end{array}$ \\
\hline
\end{tabular}

Half-lives used are 4.468E9 yr for ${ }^{238} \mathrm{U}$ and 245250 yr for ${ }^{234} \mathrm{U}$. 
Table S4. Estimated retardation factors for various U-series nuclides for saturated and unsaturated zone samples. Data from this study and (12).

\begin{tabular}{|c|c|c|c|c|c|c|}
\hline Location & Sample ID & Date Collected & $\mathbf{R}_{\mathbf{f}^{-2}}{ }^{238} \mathbf{U}$ & $\mathbf{R}_{\mathbf{f}^{-}}{ }^{230} \mathbf{T h}$ & $\mathbf{R}_{\mathbf{f}^{-26}}{ }^{226}$ & $\mathbf{R}_{\mathbf{f}^{-}}{ }^{239} \mathbf{P u}$ \\
\hline \multicolumn{7}{|l|}{ Saturated Zone: } \\
\hline PB1 & SPC1025068 & 23-Aug-06 & 370 & 900000 & 1500 & \\
\hline PB2 & SPC1025072 & 25-Aug-06 & 7140 & 250000 & 420 & \\
\hline PB3 & SPC1025069 & 24-Aug-06 & 34 & 7400 & 79 & \\
\hline PB3 & SPC1025051 & 10-Dec-03 & & & & $>34000$ \\
\hline PB4 & SPC1031127 & 8-Apr-05 & 240 & 95000 & 780 & \\
\hline Pozos Ranch & SPC1031118 & 6-Apr-05 & 130 & 5800000 & 2500 & \\
\hline Peña Blanca Ranch & SPC1031114 & 6-Apr-05 & 26 & 500000 & 690 & \\
\hline Average SZ & & & 1300 & 1300000 & 1000 & $>1000000$ \\
\hline \multicolumn{7}{|l|}{ Unsaturated Zone: } \\
\hline Range UZ & & & & $1300-260000$ & $11-230$ & \\
\hline Average UZ & & & & 73000 & 100 & \\
\hline
\end{tabular}

- Value of $R_{f}$ for ${ }^{239} P u$ determined from upper limit of ${ }^{239} \mathrm{Pu} /{ }^{238} U$ for PB3 and value of $R_{f^{-}}{ }^{238} U=34$. Based on the average $\mathrm{SZ}$ value of $\mathrm{R}_{\mathrm{f}}{ }^{238} \mathrm{U}=1300, \mathrm{R}_{\mathrm{f}}{ }^{239} \mathrm{Pu}$ would be greater than 1000000 .

- Values of $R_{f}$ for unsaturated zone samples determined from range and average of ${ }^{230} \mathrm{Th} /{ }^{238} \mathrm{U}$ and ${ }^{226} \mathrm{Ra}{ }^{238} \mathrm{U}$ ratios from the mine adit and an average $\mathrm{SZ}$ value of $\mathrm{R}_{\mathrm{f}^{-}}{ }^{238} \mathrm{U}=1300$. 